\title{
"Tartarugada": uma iniciativa de sensibilização ambiental no Parque Nacional Marinho de Fernando de Noronha (PE)
}

\author{
"Tartarugada": an undertaking of environmental awareness in the \\ Fernando de Noronha Marine National Park (PE, Brazil) \\ Miguel Ângelo Portela Pinheiro, Camila Gonçalves de Oliveira \\ Rodrigues, Rafael Azevedo Robles
}

\section{RESUMO}

A presente pesquisa teve como principal objetivo a análise da atividade conhecida como "Tartarugada", promovida pelo Projeto TAMAR-Instituto Chico Mendes de Conservação da Biodiversidade, no Parque Nacional Marinho de Fernando de Noronha (PE). Essa iniciativa consiste no acompanhamento, por parte dos visitantes, de uma atividade de pesquisa do TAMAR, na qual biólogos monitoram a Praia do Leão, onde ocorrem cerca de $80 \%$ das desovas de tartarugas-marinhas no arquipélago, da espécie Chelonia mydas. Como aporte teórico para o artigo, foram reunidas referências que tratam da relação homem-natureza e suas características ao longo da história. Também foi analisada a relação de contato direto com os processos naturais e como esta proximidade potencializa a efetividade da sensibilização e educação ambiental, especificamente inseridas no âmbito do ecoturismo. A realização da pesquisa no distrito estadual de Fernando de Noronha (PE) também tornou pertinente a busca por referências acerca do arquipélago e sua configuração em categorias de unidades de conservação, dividido entre uma área de proteção ambiental e um parque nacional marinho. Este artigo descreve as tartarugasmarinhas e alguns dos seus fatores biológicos e ecológicos que resultam no seu processo reprodutivo em terra, assim como a atuação do Projeto TAMAR na conservação destes quelônios. A metodologia utilizada englobou a pesquisa bibliográfica, o levantamento junto aos participantes da Tartarugada, por meio de um questionário semiaberto, e a análise descritiva e qualitativa das respostas. Foram entrevistados 105 participantes da atividade. As respostas fornecidas pelos visitantes indicam que a oportunidade de presenciar a nidificação da tartaruga-marinha é uma experiência de caráter sensibilizador, que pode gerar importantes reflexões sobre a questão ambiental, especialmente o ecossistema marinho. A presente pesquisa também identificou que os visitantes que não tiveram a oportunidade de presenciar a desova também se mostraram sensibilizados pela experiência, ainda que o objetivo primário a que se propuseram não tenha sido alcançado. Deste modo, a "Tartarugada" se constitui como uma iniciativa que traz à tona a problemática de proteção ambiental e busca sensibilizar seus participantes sobre a importância da conservação da biodiversidade, tendo como agente principal as tartarugas-marinhas de Fernando de Noronha (PE).

PALAVRAS-CHAVE: Sensibilização Ambiental; Ecoturismo; Tartarugas-Marinhas.

Página 1028 Revista Brasileira de Ecoturismo, São Paulo, v.6, n.5, nov 20I3-jan 20I4, Pp. I028-I05I. 
"Tartarugada": uma iniciativa de sensibilização ambiental no Parna Marinho de Fernando de Noronha

\section{ABSTRACT}

The research had as a main goal the analysis of the activity known as "Tartarugada", promoted by Projeto TAMAR- Instituto Chico Mendes de Conservação da Biodiversidade, at Fernando de Noronha Marine National Park (state of Pernambuco). This undertaking consists in accompanying a research activity of TAMAR; in which biologists monitor the Praia (beach) do Leão, where it usually occurs $80 \%$ of the seaturtles spawning at the archipelago, of the species Chelonia mydas. As theoretical support for the article, it has been gathered bibliographic references that engage on the study of close contact with nature and its processes, which has a considerable chance of improving some kind of environmental awareness and education, specifically when associated with ecotourism. The research in Fernando de Noronha (PE) also made it relevant to gather references regarding the archipelago and its present configuration as an environmental protection area and a marine national park. This article describes the sea turtles and some of their biological and ecological features that lead to their in-land spawning, as well as the Projeto TAMAR and its actions on the matter of protecting sea turtles. The methodology included the research of literature, the survey with the participants of "Tartarugada", and descriptive and qualitative analysis.105 participants of the activity were interviewed. The analysis of the information obtained was made from a mainly qualitative approach. The answers provided by the visitors indicate that the opportunity of witnessing a sea turtle's spawning it is an experience with touching features, which may evoke important reflections regarding the environmental agenda and the conservation of the marine ecosystem. The research also identified how visitors who did not have the opportunity to see the spawning revealed sensitivity towards the experience as well, even though the main goal of the experience was not achieved. Hence, the "Tartarugada" ends up being an activity that emerges the environmental protection agenda and seeks to sensitize its participants about the importance of conserving the biodiversity, in several scales and acting forefronts.

KEYWORDS: Environmental Awareness, Ecotourism, Sea Turtles.

\section{Introdução}

O cenário desta pesquisa é o Arquipélago de Fernando de Noronha (PE) (Figura 1), onde a ilha homônima foi reconhecida como Sítio do Patrimônio Mundial Natural, pela Organização das Nações Unidas para a Educação, Ciência e Cultura UNESCO ${ }^{1}$. Com uma distância de mais de trezentos quilômetros separando-a da costa brasileira, a ilha é um minúsculo ponto na imensidão azul do oceano atlântico. Mas se a porção de terra é pequena, sua beleza e fascínio são inversamente proporcionais ao seu tamanho. Turistas do Brasil e do mundo invariavelmente usam a palavra "paraíso" para descrevê-la, seja pela sua variada biodiversidade, belas paisagens ou contraste com os grandes centros urbanos.

Mas é provável que essa imagem paradisíaca provenha principalmente de suas deslumbrantes praias, de águas cristalinas e piscosidade singular. São estas praias, em especial a grande Praia do Leão, localizada no Parque Nacional Marinho de Fernando de Noronha, que servem de cenário para um singular fenômeno natural: 0 
processo de desova das tartarugas-marinhas. Fernando de Noronha é uma importante área de postura de ninhos das tartarugas-verdes (Chelonia mydas), espécie classificada como "em perigo de extinção" pela União Internacional para Conservação da Natureza - IUCN ${ }^{3}$ (2012).

Especialmente por conta dessa ameaça, instalou-se na ilha uma base do Centro Brasileiro de Proteção e Pesquisa das Tartarugas Marinhas, Projeto TAMARICMBIO (Instituto Chico Mendes de Conservação da Biodiversidade) ${ }^{4}$. Esta iniciativa visa proteger e garantir a continuidade do ciclo de vida dessas tartarugas, através do monitoramento das áreas de desova e alimentação. Devido ao grande fluxo turístico da ilha, o TAMAR passou a promover atividades que suscitam a sensibilização e educação ambiental dos moradores e turistas.

Uma dessas atividades é a "Tartarugada", que consiste em uma atividade de sensibilização ambiental, na qual seus participantes podem acompanhar o trabalho de monitoramento noturno na Praia do Leão, na tentativa de registrar alguma desova das tartarugas in loco. O objetivo principal da "Tartarugada" é sensibilizar os participantes no que tange à proteção das tartarugas-marinhas e do ecossistema marinho, tendo como importante premissa a proximidade com a natureza e seus processos. $O$ presente trabalho visa analisar de que forma este objetivo tem sido alcançado. Para tanto, foi desenvolvida uma pesquisa junto aos visitantes com objetivo de analisar a experiência vivenciada e compreender a repercussão da atividade em termos de conhecimento e sensibilização frente às questões ambientais.

Inicialmente, o artigo apresenta um balizamento conceitual a partir da abordagem da relação homem-natureza e seu recente movimento de ressignificação dos espaços naturais, fortalecido pela criação de áreas protegidas como o Parque Nacional Marinho de Fernando de Noronha. Também são apresentadas algumas referências teóricas que sustentam a promoção da educação ambiental através de atividades de ecoturismo, segmento turístico originalmente vinculado aos preceitos de conservação do patrimônio natural. Posteriormente, será apresentado um breve histórico e caracterização do Parque Nacional Marinho de Fernando de Noronha, seguido pela apresentação das tartarugas-marinhas e do Projeto TAMAR e, finalmente, serão analisados os resultados obtidos com a aplicação do questionário junto aos participantes da "Tartarugada".

Com base na pesquisa realizada, pode-se dizer que a "Tartarugada" tem se mostrado uma atividade inovadora, que traz à tona diversos sentimentos e questionamentos, que serão explorados ao longo deste artigo.

\section{Metodologia}

Os procedimentos metodológicos utilizados na pesquisa podem ser divididos em três etapas. No primeiro momento, foi realizada uma pesquisa bibliográfica, considerando os principais temas do artigo que tratam da educação ambiental e do ecoturismo em áreas protegidas. Esse levantamento bibliográfico subsidiou a elaboração do instrumento de pesquisa utilizado na "Tartarugada". A segunda etapa

Página 1030 Revista Brasileira de Ecoturismo, São Paulo, v.6, n.5, nov 20I3-jan 20I4, Pp.1028-I05I. 
"Tartarugada": uma iniciativa de sensibilização ambiental no Parna Marinho de Fernando de Noronha

consistiu na aplicação dos questionários junto aos participantes da atividade. Por fim, na terceira etapa foram realizadas a tabulação e a análise das informações obtidas.

A atividade da "Tartarugada" é o objeto central de estudo deste artigo. Esta iniciativa do Projeto TAMAR - Base de Fernando de Noronha-PE acontece durante o monitoramento da Praia do Leão. De dezembro a julho (temporada reprodutiva em Fernando de Noronha), no período noturno, um pesquisador do TAMAR fica a postos na Praia do Leão, localizada no Parque Nacional Marinho de Fernando de Noronha, para desenvolver o trabalho de registro de desovas das tartarugas-verdes (Chelonia mydas). Esta iniciativa, mesmo não tendo o ecoturismo como proposta inicial, concilia a atividade de pesquisa e monitoramento com a visitação. A tentativa de flagrar a nidificação é um processo que está totalmente sujeito às características da própria tartaruga, de modo que é possível, através de pesquisas e dados, ter alguma noção de quando o animal irá desovar, porém não se pode precisar o exato dia em que ocorrerá.

Os participantes da atividade estão sujeitos ao acaso de não conseguir presenciar a desova. Contudo, independentemente da oportunidade de registrar a desova, a "Tartarugada" possibilita uma experiência junto aos trabalhos de pesquisa e monitoramento do TAMAR. Assim, com o objetivo de analisar os efeitos da atividade em termos de sensibilização de seus participantes, foi realizado um levantamento, de tipo survey, por meio de um questionário semiaberto. As questões abertas foram analisadas a partir de palavras-chave e depoimentos realizados pelos participantes. Entende-se que estas são as questões que denotam uma maior subjetividade e que podem apontar elementos de análise mais precisos sobre como a atividade pode ter impactado o participante. As palavras-chave identificadas foram analisadas quantitativamente, de maneira a sistematizar os termos mais utilizados nos depoimentos dos participantes da tartarugada.

Conforme salientado anteriormente, os visitantes da "Tartarugada" podem ou não presenciar a desova. $O$ fato de presenciar ou não a desova foi tomado como um elemento que tende a influenciar a opinião e a experiência do participante. Desse modo, a pesquisa considerou três grupos distintos: aqueles que presenciaram a desova; aqueles que viram alguma tartaruga, porém não presenciaram a desova ("meia-lua"" ou "sem desova"); e aqueles que não viram desova ou tartarugas. No período de 23 de janeiro de 2012 a 10 de maio de 2012 foram entrevistados ao todo 105 participantes da atividade, sendo 98 turistas e 7 moradores. Os questionários foram respondidos pelos visitantes após 10 horas de atividade, que começa às 20 horas e termina às 6 horas.

Serão apresentadas as tabulações e a análise das respostas dos questionários (apêndice 1), buscando situar o alcance das finalidades de sensibilização e educação ambiental da atividade.

Página I03I Revista Brasileira de Ecoturismo, São Paulo, v.6, n.5, nov 2013-jan 20I4, pp. I028-I05I. 


\section{Um breve apontamento sobre a relação homem-natureza}

A relação antrópico-natural se modificou radicalmente com o racionalismo já crescente na antiguidade. Se na pré-história, o homem guardava reverência em relação à natureza, na Grécia Antiga, Tales de Mileto já buscava desvendar os seus mistérios ainda com certa saudação. As reflexões de Sócrates marcaram o início de um pensamento antropocêntrico, enquanto Platão dicotomizou a relação homemnatureza. Na idade média, as religiões monoteístas deram continuidade ao processo de dessacralização da natureza, pois transferiram valores místicos antes atribuídos aos bens naturais para uma única entidade, Deus (MORIMOTO; SALVI, 2009).

Mas esse processo de dessacralização da natureza sacramentou-se de vez a partir da ciência moderna capilarizada por valores cartesianos. René Descartes promoveu a imagem da natureza como uma máquina a serviço do homem, o que veio a embasar sua exploração desmedida nos séculos subsequentes. $O$ racionalismo antropocêntrico de Descartes tornou "natural" os maus-tratos aos animais, pois estes seriam seres sem alma, passíveis de serem molestados a serviço da razão humana. Francis Bacon também deu sua contribuição ao vincular a imagem da natureza a uma figura feminina, o que, em uma sociedade patriarcal, contribuiu consideravelmente para legitimar o uso exacerbado dos recursos naturais (CAPRA, 2002).

Toda esta conjuntura culminou na Revolução Industrial, que transferiu o centro econômico do meio rural para o urbano. O êxodo rural e a consequente superpopulação das cidades, a poluição, a saturação da infraestrutura urbana; são razões pelas quais surgiu um movimento de revalorização da natureza, no epicentro de uma nascente sociedade urbano-industrial (ibid.). Estas ideias foram ganhando corpo e, ao longo dos séculos, resultaram em diversos movimentos e acordos internacionais, em especial a Convenção da Diversidade Biológica, já em 1992. Esta previa uma série de medidas mitigadoras para os impactos ambientais ocasionados pelas circunstâncias supracitadas, dentre elas a criação de áreas protegidas e a promoção de um turismo sustentável (BENSUSAN, 2006).

Neste cenário de idealização das áreas naturais, o turismo ganhou bastante relevância na medida em que já era um fenômeno incrustado na sociedade contemporânea e poderia ser utilizado como forma de disseminar a mensagem ecológica de maneira eficaz. O ecoturismo ascende, sendo atualmente o segmento turístico de maior crescimento (BRUHNS, 2009), um sintoma da mudança de foco de alguns setores da sociedade atual. Este nicho da atividade turística, dentre diversos conceitos e princípios, pode ser caracterizado como tendo algumas idiossincrasias primordiais: promoção da sustentabilidade (ambiental, social, econômica, cultural), educação ambiental e envolvimento das comunidades locais. Teoricamente, é um conceito louvável, porém as iniciativas que se autoproclamam "ecoturísticas" devem ser analisadas sob um olhar crítico. Devido ao crescimento desta demanda, o trade turístico tem pintado de verde algumas práticas não consonantes com o cerne do ecoturismo (ibid.). Por outro lado, também é preciso exaltar as iniciativas que o praticam, de fato.

Página 1032 Revista Brasileira de Ecoturismo, São Paulo, v.6, n.5, nov 20I3-jan 20I4, Pp.1028-I05I. 
"Tartarugada": uma iniciativa de sensibilização ambiental no Parna Marinho de Fernando de Noronha

A tartarugada, promovida pelo Projeto TAMAR, potencialmente se encaixa no grupo de iniciativas "ecoturísticas", especialmente por fatores como a gratuidade concedida a moradores locais, a proposta de sensibilização e educação ambiental e a reversão integral do valor pago por turistas na pesquisa e conservação das tartarugas -marinhas. É relevante frisar que o êxito das iniciativas do TAMAR está pautado principalmente no envolvimento com moradores locais ${ }^{7}$. Muitas comunidades costeiras onde o projeto se instalou utilizavam as tartarugas-marinhas como fonte de alimento e renda através da venda de sua carne, ovos e derivados. A chegada do programa nesses locais se deu através de interação comunitária, onde houve um relevante trabalho de sensibilização e adaptação dos moradores destas localidades (VIEITAS; MARCOVALDI, 1997).

Dentre as iniciativas promovidas pelo Projeto TAMAR, a "Tartarugada" é uma oportunidade singular de presenciar a desova de uma tartaruga-marinha, experiência com grande possibilidade de impactar o emocional de quem tem esse privilégio. As sensações suscitadas pelo contato direto com a natureza tendem a conscientizar a pessoa do seu papel na conservação daquele ambiente (BRUHNS, 2009). A cabana de apoio do TAMAR para o monitoramento da desova, rústica e diminuta, não deixa de ser uma chance do indivíduo se reaproximar de valores perdidos na sociedade materialista atual, como o desapego de bens materiais.

O turismo constitui-se em uma atividade de lazer por excelência. Geerdink e Neiman (2009) afirmam que conceitos e ensinamentos são melhor retidos pelo cérebro humano em momentos de relaxamento. As práticas de educação ambiental são permeadas por essa idéia, pois a mesma deve ser realizada através do contato estreito com a natureza, proporcionado principalmente em momentos de lazer. Neste conjunto de pressupostos, é possível vislumbrar que as pessoas podem ser levadas à reflexão ao presenciar a desova de uma tartaruga-marinha. Este é um processo tão "perfeitamente natural" que talvez seja irresistível até para o antropocentrismo racionalista tipicamente cartesiano. As respostas dos questionários respondidos pelos participantes da atividade, que serão apresentadas nesse artigo, elucidam o desígnio deste questionamento.

A seguir será apresentando um breve histórico sobre o Arquipélago de Fernando de Noronha, com o objetivo de ilustrar a importância ecológica do local, que atrai inúmeras iniciativas de conservação, e também o coloca como um importante destino de ecoturismo.

\section{Fernando de Noronha: de naufrágio à Parque Nacional Marinho}

O Arquipélago de Fernando de Noronha é um conjunto de ilhas oceânicas de origem vulcânica, localizado na faixa equatorial do Oceano Atlântico ( ${ }^{\circ} 50^{\prime}$ S-32 ${ }^{\circ}$ 24 'W) e composto por 18 ilhas, ilhotas e rochedos. O arquipélago encontra-se no topo de um edifício submarino de $4000 \mathrm{~m}$ de profundidade e $60 \mathrm{~km}$ de diâmetro. Estando no largo da costa do nordeste brasileiro, dista $545 \mathrm{~km}$ de Recife, $345 \mathrm{~km}$ de Natal, e $2600 \mathrm{~km}$ da costa africana (MOHR et al., 2009). A ilha principal, Fernando de Noronha, é a única a ser habitada e possui $18,4 \mathrm{~km}^{2}$. Seu clima é tropical com duas

Página 1033 Revista Brasileira de Ecoturismo, São Paulo, v.6, n.5, nov 2013-jan 20I4, Pp. I028-I05I. 
estações bem definidas: a seca, de setembro a março, e a chuvosa, de abril a agosto. Desde 1988, é um distrito estadual de Pernambuco (TEIXEIRA et al, 2003).

O arquipélago foi descoberto por ocasião do $1^{\circ}$ naufrágio da história do Brasil, em 10 de agosto de 1503. Uma das naus da expedição comandada por Gonçalo Coelho se chocou contra um conjunto de rochas submersas hoje conhecidas como Pedras Secas. Gonçalo Coelho ordenou que Américo Vespúcio pegasse um barco de apoio para se refugiar na ilha secundária que viria a ser chamada de Ilha Rata. A enseada onde o navegador desembarcou foi batizada de "Ressureta". Deste modo, Américo Vespúcio entrou para a história como o "descobridor" de Fernando de Noronha (SILVA, 2007).

A expedição comandada por Gonçalo Coelho era financiada por Fernão de Loronha e esta é a razão pela qual a Coroa Portuguesa doou a ilha recém "descoberta" para este fidalgo português. É curioso o fato de que o donatário nunca chegou a pisar na ilha que viria a ser batizada em sua homenagem; Fernão de Loronha enviou alguns familiares para tomar posse da terra. Ao chegarem à ilha, os parentes de Loronha não permaneceram muito tempo por conta das condições inóspitas que o local apresentava. A família se dirigiu para o que viria a ser a Capitania Hereditária de Pernambuco, de onde supostamente mantinham controle do arquipélago (ibid.).

Por mais de 200 anos após o seu reconhecimento, a ilha foi ignorada pelos portugueses, concentrados na ocupação e proteção da costa continental brasileira. Porém, para diversos navegadores, era bastante conveniente uma ilha tropical em uma rota de navegação muito utilizada. Entre 1503 e 1737, o arquipélago serviu como área de descanso e abastecimento para navegações de origens diversas. O clima tropical, amenizado pelos fortes ventos; a abundância de peixes, golfinhos, tartarugas e aves marinhas com seus ovos; o cenário paradisíaco em si; são razões pelas quais a ilha desocupada se tornou convidativa para as embarcações que por ali passavam. Navegantes de várias nacionalidades passaram por Noronha nesse período; holandeses, franceses, italianos, espanhóis, ingleses, alemães e até suecos, suíços e belgas (ibid.).

Em 1737, Portugal tomou posse definitiva do arquipélago, expulsou os invasores e construiu um sistema de defesa tido como o mais eficaz do século XVIII. Vários fortes estrategicamente posicionados acima de praias, baías e enseadas que seriam potenciais áreas de atracação; era o início da colônia correcional. Entre o contínuo envio de supostos párias como ciganos e capoeiristas para o isolamento e passagens marcantes de Debret e Darwin, a ilha foi utilizada como presídio comum até 1938, quando se tornou presídio político. Neste longo período ocorreu grande parte do desmatamento da ilha, pois os militares cortavam a vegetação para poderem avistar presos que arriscassem a fuga. Hoje a ilha possui aproximadamente apenas $7 \%$ de sua cobertura vegetal original (ibid.).

Em 1942, o arquipélago foi identificado como área estratégica para a Segunda Guerra Mundial, sendo ocupado por estadunidenses. Esta situação se intensificou 


\section{"Tartarugada": uma iniciativa de sensibilização ambiental no Parna Marinho de Fernando de Noronha}

durante a Guerra Fria, quando Fernando de Noronha se tornou posto de observação de mísseis teleguiados. Nos anos seguintes, o controle da ilha foi sendo revezado entre as forças armadas e ministérios diversos. Esta situação perdurou até a década de 80, quando a imparidade ecológica do local chamou a atenção de instituições ambientalistas nacionais e internacionais (ibid.).

Em 1980, a IUCN identificou a região como sendo de "alta prioridade" para a conservação, o que foi um indicativo para a criação da Área de Proteção Ambiental (APA) de Fernando de Noronha, Atol das Rocas e Arquipélago de São Pedro e São Paulo, em 1986 (TEIXEIRA et al, 2003). Dois anos depois, é criado o Parque Nacional Marinho de Fernando de Noronha (PARNAMAR-FN), com influência direta do Projeto TAMAR, o que será explanado mais adiante. No mesmo ano de 1988, o arquipélago é reintegrado a Pernambuco como Distrito Estadual. Em 2001, a UNESCO reconhece Fernando de Noronha como "Sítio do Patrimônio Mundial Natural".

Vale ressaltar que a Área de Proteção Ambiental (APA) é uma unidade de conservação de uso sustentável que visa primariamente atenuar os impactos do processo de ocupação humana, conservar a biodiversidade e promover a sustentabilidade dos recursos. É uma categoria de unidade de conservação menos restritiva do que o parque nacional (BENSUSAN, 2006). Toda a área habitada da ilha de Fernando de Noronha está inserida na APA, o que corresponde a $30 \%$ da área do arquipélago. Já o Parque Nacional é uma unidade de conservação de proteção integral, com uma série de restrições no seu manejo, criada para proteger áreas de grande diversidade biológica e beleza cênica. Visitas são permitidas com objetivos variados que vão desde o lazer até a pesquisa científica. Mas essas atividades devem ocorrer de acordo com as normas estabelecidas no plano de manejo da área, documento que rege a unidade de conservação e delimita seu zoneamento territorial (BENSUSAN, 2006). O Parque Nacional Marinho de Fernando de Noronha ocupa cerca de $70 \%$ do arquipélago, além da área marinha até onde a isóbata atinge 50 metros no entorno de quase todo o conjunto de ilhas (TEIXEIRA et al, 2003) (Figura 1).

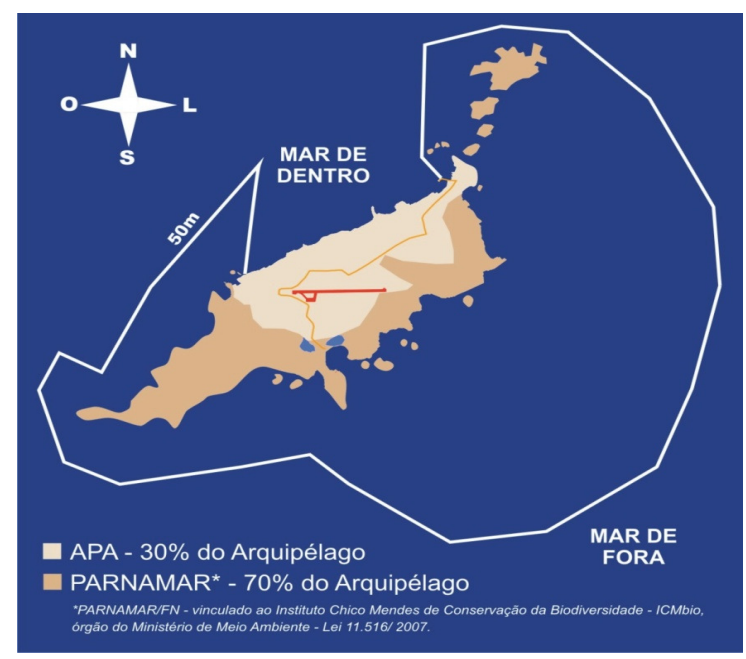

Figura 1: representação do Arquipélago de Fernando de Noronha e sua divisão em unidades de conservação. Fonte: Banco de imagens do Projeto TAMAR.

Figure 1: portrayal of the Fernando de Noronha Archipelago and its division into protected areas.

Source: Projeto TAMAR's file.

Página I035 Revista Brasileira de Ecoturismo, São Paulo, v.6, n.5, nov 2013-jan 20I4, pp. I028-I05I. 
Este resgate histórico se faz pertinente para contextualizar o cenário no qual a fauna e flora noronhenses sofreram graves impactos dos quais ainda não se recuperaram, mesmo com a atual conjuntura da ilha que é inteiramente protegida em unidades de conservação. Pode-se exemplificar essa situação com o caso das tartarugas-marinhas. Estes animais sofreram um declínio acentuado nas suas populações na época das grandes navegações, quando a ilha era ponto de descanso e abastecimento de embarcações. Nas águas cristalinas de Noronha, os navegantes encontraram tartarugas-marinhas em abundância. Logo foi percebido que as mesmas, quando mantidas em local úmido e sombreado (como o porão de um navio), conseguem viver meses fora d'água. Deste modo, as tartarugas se transformaram em uma fonte única de carne fresca durante os longos meses que eram passados em alto -mar (SILVA, 2007). Grandes quantidades de tartarugas-marinhas foram mortas e estas populações não se recuperaram totalmente até hoje, por razões específicas desses animais, que serão explicitadas mais adiante.

\section{Tartarugas-marinhas e o berçário noronhense}

O estudo sobre as tartarugas-marinhas apresenta uma série de desafios e mistérios para os pesquisadores. São animais migratórios, solitários, de longo ciclo de vida e passam boa parte da vida submersos, circunstâncias que dificultam o seu estudo. Estes animais fazem parte da mais antiga linhagem de répteis, tendo evoluído de animais terrestres que foram se adaptando ao ambiente aquático marinho. Alguns traços evolutivos comprovam essa afirmação como a respiração pulmonar e a gradual adaptação dos membros que apresentam falanges ósseas mais alongadas resultando em uma nadadeira. Outra característica que sustenta essa teoria é o fato de as tartarugas-marinhas necessitarem vir à terra para a postura de seus ninhos. Este é o momento sobre o qual se tem mais informações e conhecimento em relação às tartarugas-marinhas, devido à maior facilidade de observação e coleta de dados (LUTZ et al., 2003).

Conforme citado acima, as tartarugas-marinhas possuem longo ciclo de vida; supõe-se que vivem entre 80 e 100 anos, variando de acordo com a espécie. A maturidade sexual desses animais é tardia; no caso da espécie Chelonia mydas, começam a se reproduzir por volta dos 25 anos (HIRTH, 1980 apud GOMES et al, 2006). A cada temporada reprodutiva, uma única tartaruga desova entre 4 e 8 vezes e, em cada ninho, são postos em média 120 ovos. Sendo assim, uma única tartaruga pode chegar a pôr quase 1000 ovos em uma única temporada. Porém, dados indicam que, de cada 1000 filhotes, apenas um ou dois chegam à fase adulta (ibid.). Quando nascem, as tartarugas são pequeninas e frágeis, muito suscetíveis à predação natural por diversos animais, desde caranguejos, passando por aves marinhas até os tubarões, além de terem muita dificuldade em se alimentar. As tartarugas que atingem as fases juvenil e adulta se tornam alvos, também, da ação humana. Interações com a pesca e pressão antrópica são os maiores impactos negativos sobre estes répteis marinhos nos dias atuais (LUTZ et al., 2003).

Página 1036 Revista Brasileira de Ecoturismo, São Paulo, v.6, n.5, nov 20I3-jan 20I4, Pp.1028-I05I. 
"Tartarugada": uma iniciativa de sensibilização ambiental no Parna Marinho de Fernando de Noronha

Os fatos acima relatados são motivos que contribuem para que estas tartarugas figurem nas listas de espécies ameaçadas de extinção. As populações de tartarugas-marinhas que experimentaram um declínio acentuado demorarão muitos anos para se recuperar totalmente. Fernando de Noronha é um exemplo crasso desta afirmativa. Localidades como o Atol das Rocas $(R N)$ e a llha de Trindade (ES), mesmo possuindo áreas consideravelmente menores em relação à Noronha, recebem uma quantidade bastante superior de desovas, seja em números relativos ou absolutos. A llha de Trindade, segundo maior sítio de desovas do Atlântico Sul, recebe em média 3600 desovas por temporada; o Atol das Rocas, com uma área terrestre apenas um pouco maior que a Praia do Leão, em Fernando de Noronha, costuma receber em torno de 335 desovas $\left(\right.$ SITAMAR $\left.^{8}\right)$.

Em terras noronhenses, se o número de desovas ultrapassa 100, como em 2012, já é motivo de bastante comemoração, pois a média desde o início das atividades do TAMAR no arquipélago é de 59 ninhos por temporada (ibid.). A explicação para essa discrepância é o fato de Fernando de Noronha receber impactos da ocupação humana há mais de 500 anos. Pode-se resgatar o exemplo citado anteriormente dos navegadores dos séculos XVI e XVII que utilizavam as tartarugasmarinhas como fonte de carne fresca para as longas jornadas além-mar. É possível supor que, em Noronha, as tartarugas sofreram consideráveis impactos e levarão séculos para se recuperar de tamanho abalo nas suas populações.

As tartarugas-marinhas também possuem um senso de orientação incrivelmente apurado; os indivíduos adultos voltam para copular e desovar na mesma região em que nasceram, fenômeno que é denominado de filopatria. Acreditase que este incrível fato deva-se à orientação destes animais pelo campo magnético da Terra ou por identificação de características físico-químicas das praias e regiões onde eclodiram (LOHMANN; LOHMANN, 1994). Na verdade não há provas suficientes que confirmem ou refutem estas hipóteses, o que torna a filopatria quelônia um mistério até mesmo para os seus estudiosos. Uma hipótese bastante propalada é de que a presença de magnetita no cérebro desses animais torne possível a orientação pelo campo magnético terrestre, por onde as tartarugas se direcionam no momento de voltar para a sua área de nascimento e dar início a um novo ciclo de vida (LUTZ et al., 2003).

Por serem animais migratórios, acabam cruzando oceanos e áreas sob jurisdição de diversos países; daí a importância de existir um trabalho conjunto internacional para a conservação dessas espécies. Não seria eficaz que determinados países trabalhassem na conservação das tartarugas se outros países costeiros não aderissem ao mesmo trabalho, pois as tartarugas protegidas em um local poderiam ser mortas em outro, tornando a ação ineficiente. Por isso, esses animais são também classificados como "recurso natural compartilhado" (FUNDAÇÃO PRÓ-TAMAR, 2000). Nos anos 70 o governo brasileiro sofria pressão internacional pela criação de um programa de proteção das tartarugas. Países como Suriname e Venezuela já os possuíam, enquanto o Brasil, com quase $8000 \mathrm{~km}$ de costa em águas tropicais e subtropicais (onde há maior concentração de tartarugas-marinhas), não contribuía com este trabalho (ibid.).

Página 1037 Revista Brasileira de Ecoturismo, São Paulo, v.6, n.5, nov 2013-jan 20I4, Pp.1028-I05I. 
As tartarugas-marinhas têm grande importância nos mais diversos segmentos. A gigantesca tartaruga-de-couro (Dermochelys coriacea), por exemplo, é um dos poucos animais que se alimenta prioritariamente de águas-vivas. Grandes declínios na sua população significam um aumento considerável na quantidade de águas vivas, que se alimentam de larvas de peixe. Logo, o aumento de águas-vivas traz abalo considerável para a indústria pesqueira. A tartaruga-de-pente (Eretmochelys imbricata) se alimenta de esponjas marinhas, não permitindo que estas se proliferem em demasia e sufoquem recifes de corais. A tartaruga-verde, única espécie herbívora, chega a ingerir mais de uma tonelada de algas marinhas por ano. Quando esses animais sobem à terra para desovar, transferem parte desse grande acúmulo de energia para a areia. A decomposição das cascas dos ovos significa nutrientes no solo e energia para plantas e animais (LUTZ et al., 2003). A proteção das tartarugasmarinhas é de extrema importância para o ecossistema marinho e a natureza em geral, conforme exemplificado acima, o que tem motivado a criação de iniciativas que visem a conservação desses animais.

No Brasil, a criação do Centro Brasileiro de Proteção e Pesquisa das Tartarugas Marinhas (Projeto TAMAR) ocorreu em 1980, quando pouco se sabia no país sobre esses animais, que já figuravam nas listas de espécies ameaçadas de extinção, da IUCN. A missão do TAMAR era restabelecer o ciclo reprodutivo das tartarugas-marinhas, que vinha sendo severamente prejudicado pela ação humana. Após dois anos de intensas pesquisas pelo litoral brasileiro, foram criadas as três primeiras bases do Projeto na Praia do Forte (BA), Regência (ES) e Pirambu (SE), com o objetivo de contemplar áreas de reprodução de 4 das 5 espécies existentes no Brasil (FUNDAÇÃO PRÓ-TAMAR, 2000).

Em 1984, o TAMAR chegou ao Arquipélago de Fernando de Noronha, com o intuito de estudar e monitorar as áreas de desova das tartarugas-verdes (Chelonia mydas) que, no Brasil, se reproduzem majoritariamente em ilhas oceânicas. A Praia do Leão, área de maior incidência de nidificação, foi decretada como área de uso especial do TAMAR para pesquisa e conservação da espécie. Por conseguinte, a Praia do Leão foi o embrião para a criação do Parque Nacional Marinho de Fernando de Noronha, por conta das desovas de tartarugas-marinhas. Processo semelhante ocorreu em Regência (ES) e Pirambu (SE), onde foram criadas reservas biológicas para proteger as áreas de desova de outras duas espécies; tartarugas-de-couro (Dermochelys coriacea) e oliva (Lepidochelys olivacea), respectivamente (ibid.).

Desde a chegada do TAMAR a Fernando de Noronha, o esforço tem sido direcionado à proteção das tartarugas da ilha, que além de ser uma importante área de desova e alimentação das tartarugas-verdes, também é área de alimentação das tartarugas-de-pente (Eretmochelys imbricata). Porém já houve registro das 5 espécies existentes no Brasil nas águas do arquipélago, sendo assim, um ponto estratégico na conservação e pesquisa desses animais (BELLINI; SANCHES, 1998). O trabalho do TAMAR possui grande parte do seu foco na manutenção da reprodução das tartarugas, razão pela qual o monitoramento das praias que são áreas de desova é um ponto-chave para o sucesso da iniciativa.

Página 1038 Revista Brasileira de Ecoturismo, São Paulo, v.6, n.5, nov 20I3-jan 20I4, Pp.1028-I05I. 
"Tartarugada": uma iniciativa de sensibilização ambiental no Parna Marinho de Fernando de Noronha

Em Noronha, o TAMAR realiza esse monitoramento entre dezembro e julho na Praia do Leão, na face meridional do Arquipélago, banhada pelo "Mar de Fora" . É importante ressaltar que outras praias da ilha também são potenciais áreas de desova, porém o Projeto TAMAR concentra esforços na Praia do Leão por esta ser historicamente a de maior incidência de desovas de tartarugas. Cerca de $80 \%$ das posturas de ninhos no arquipélago ocorrem nesta praia (BELLINI et al, 2000), o que pode ser explicado pelo fato de a mesma ser a mais isolada das praias noronhenses.

\section{"Tartarugada" e o monitoramento da desova de tartarugas}

A "Tartarugada" consiste basicamente no acompanhamento do trabalho de monitoramento noturno da Praia do Leão, na tentativa de flagrar alguma tartaruga em atividade reprodutiva. $O$ acesso até essa praia se dá através de uma caminhada de 20 a 30 minutos por uma estrada de terra (Estrada Velha do Leão). Ao chegar na praia, moradores e turistas se deparam com o mais revolto mar de Fernando de Noronha, potencialmente perigoso pelas fortes correntes e potência das ondas.

Por conta da sua relativa inospitabilidade, a Praia do Leão (Figura 2) foi sendo deixada de lado pelos roteiros turísticos tradicionais e pelos próprios moradores da ilha, sendo a praia noronhense menos danificada por ações antrópicas. As tartarugasverdes (Chelonia mydas) naturalmente se refugiaram neste local para nidificar. A criação do Parque e suas inerentes restrições se deram por conta das desovas, fato que contribuiu significativamente para a manutenção das nidificações na área. Dados levantados pelo próprio TAMAR demonstram que as praias que concentraram maior número de desovas na ilha são Leão e Sancho (BELLINI et al, 2000) e não é uma coincidência que ambas estejam inseridas na área do Parque Nacional Marinho, por conseguinte, livres de iluminação artificial e ocupação da faixa de areia e seu entorno.

A Praia do Leão existe graças à Pedra do Leão (que veio a batizar a praia) e ao Morro da Viuvinha. Estes são dois rochedos localizados no mar, de frente para a faixa de areia. Ao longo da formação geológica da ilha, este posicionamento bloqueou parte da ação erosiva dos fortes ventos alísios do sudeste e das possantes correntes marinhas que viriam a desaguar na sua orla, sendo um fator determinante para a existência da Praia do Leão. Localizada no lado oriental do arquipélago, onde o mar é mais agitado, esta praia é potencialmente perigosa. É interessante notar que a existência de praias no "Mar de Fora" noronhense é condicionada por rochedos ou recifes que bloqueiam a erosão advinda do oceano e dos fortes ventos (TEIXEIRA et al, 2003).

O trabalho de monitoramento da Praia do Leão, que apresenta cerca de 480 metros de extensão, consiste em rondas realizadas a pé a cada hora, de uma ponta a outra da praia, em busca de rastros de uma possível tartaruga em processo de nidificação. Há uma cabana de apoio do TAMAR (Figura 3), com colchões infláveis e redes para descanso. A instalação é rústica e os participantes são previamente avisados desta condição. Para se engajar na iniciativa, os turistas e moradores agendam a atividade previamente e se encontram com os pesquisadores do TAMAR na Estrada Velha do Leão para dali seguirem até a Praia do Leão. Há um número

Página 1039 Revista Brasileira de Ecoturismo, São Paulo, v.6, n.5, nov 2013-jan 20I4, Pp.1028-105I. 
Pinheiro, M.A.P.; Rodrigues, C.G.O.; Robles, R.A.

máximo de quatro pessoas por "Tartarugada" (excluindo o pesquisador do TAMAR). Moradores não pagam para participar da atividade, enquanto os turistas contribuem com cinquenta reais ( $R \$ 50,00)$ para poderem acompanhar o monitoramento. Este valor é integralmente revertido para a pesquisa e conservação das tartarugasmarinhas.

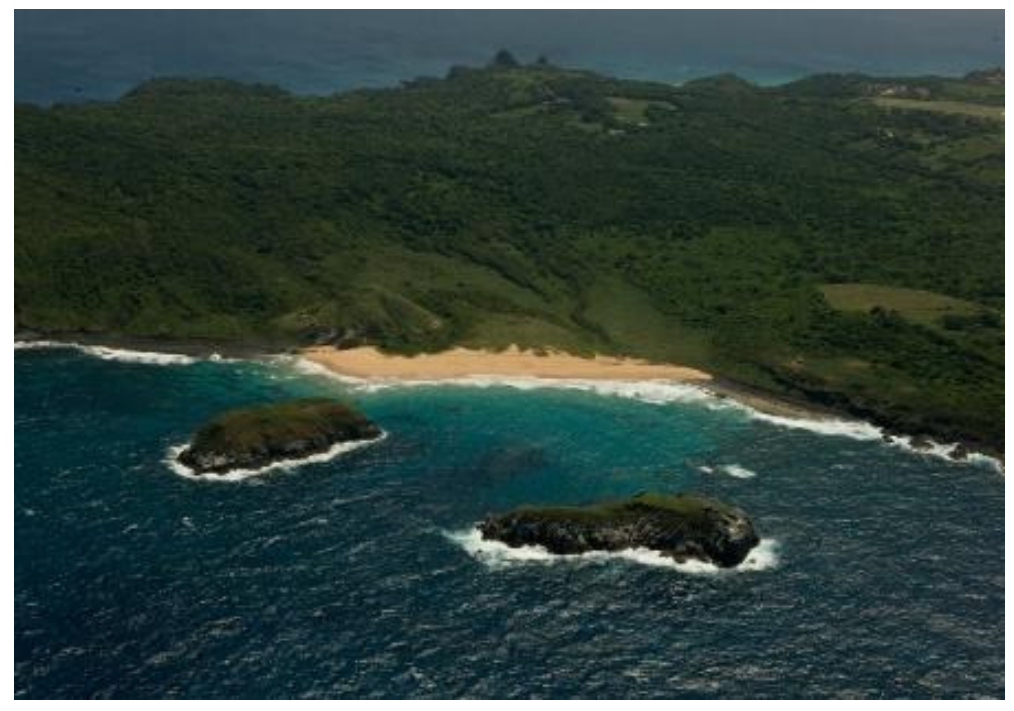

Figura 2: Praia do Leão. Em primeiro plano, a Pedra do Leão, à direita, e o Morro da Viuvinha, à esquerda. Ao fundo, a vegetação circundante que torna esta praia a mais isolada em Fernando de Noronha. Fonte: Banco de imagens do Projeto TAMAR.

Figure 2: Praia do Leão (Leão Beach). On the forefront, the Leão Rock, to the right, and the Viuvinha Rock, to the left. On the background, the surrounding vegetation that makes this beach the most isolated in Fernando de Noronha. Source: Projeto TAMAR's file.

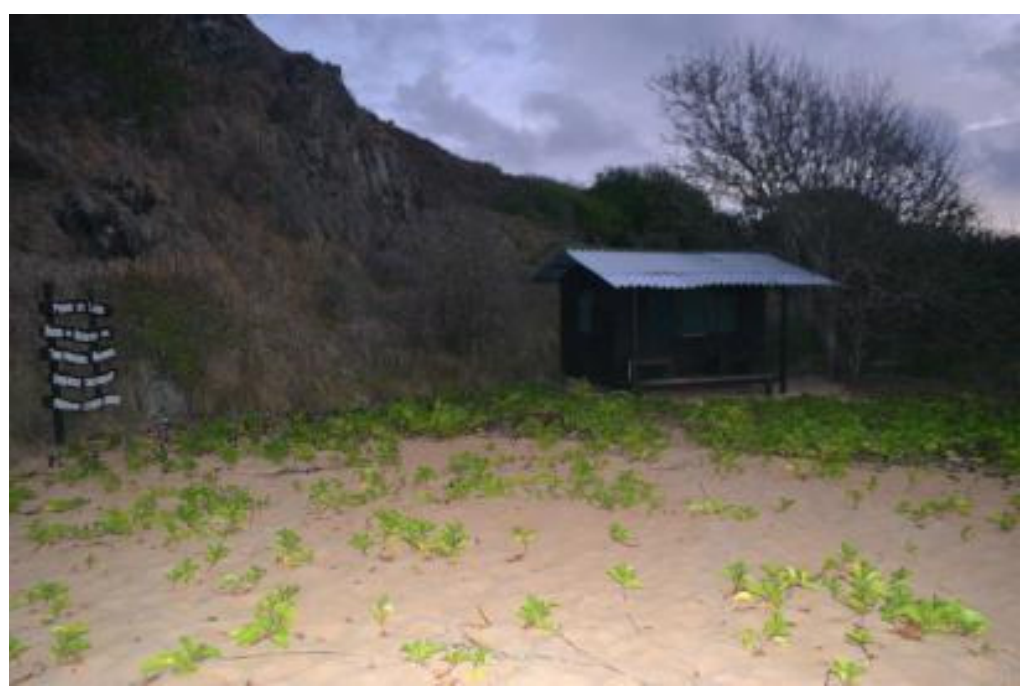

Figura 3: Cabana de apoio do Projeto TAMAR. Fonte: arquivo pessoal do autor.

Figure 3: Projeto TAMAR's support cabin. Source: author's personal file.

Página 1040 Revista Brasileira de Ecoturismo, São Paulo, v.6, n.5, nov 20 I3-jan 20I4, Pp.1028-I05I. 
A desova das tartarugas-marinhas, em suma, consiste no processo de saída das tartarugas da água para a faixa de areia, onde escolhem um local de sua preferência e fazem sua "cama" com ambos os pares de nadadeiras. Em seguida, cavam um ninho de aproximadamente cinquenta centímetros de profundidade com as nadadeiras posteriores e iniciam a postura de ovos (Figura 4), quando entram em uma espécie de "transe" que só termina no momento em que o último ovo é expelido pela cloaca do animal (LUTZ et al., 2003). É neste período que os pesquisadores do TAMAR fazem a biometria e medição do indivíduo. Após a postura de ovos, as tartarugas cobrem o ninho e o disfarçam por um longo período, tornando difícil para os próprios pesquisadores que presenciaram o fenômeno identificarem o local exato onde ocorreu.

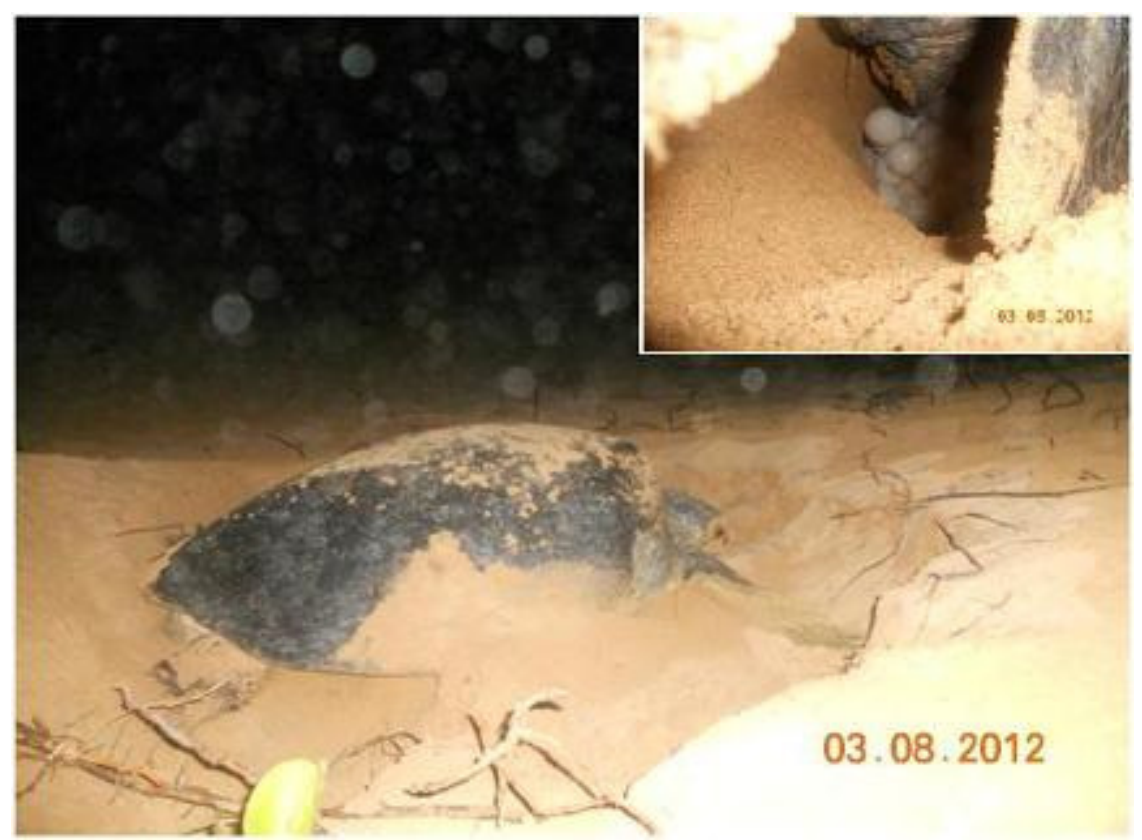

Figura 4: Tartaruga-Verde (Chelonia mydas) fazendo a sua "cama", para então iniciar a desova. Em destaque, o momento da postura de ovos. Fonte: arquivo pessoal dos autores.

Figure 4: Green-turtle (Chelonia mydas) making its bed so as to start the spawning. Featured above, the moment when the turtle lays the eggs. Source: author's personal file.

As tartarugas-marinhas se mostram bastante criteriosas quanto à escolha do local ideal para sua nidificação. Por critérios próprios, ainda não inteiramente compreendidos pelos pesquisadores, estes animais podem até subir à areia e desistir de nidificar, procurando outro local adequado ou simplesmente voltando para o mar (Figura 5) sem finalizar o processo. Esse acontecimento é chamado pelos pesquisadores do TAMAR de "meia-lua" quando o animal apenas se arrasta pela praia, ou "sem-desova", quando além de se arrastar, ainda chega a cavar parte da cama ou até mesmo a câmara dos ovos. A temporada reprodutiva em Noronha vai de dezembro a julho, quando é proibido permanecer nas praias após às 18 horas, pelo fato de as tartarugas subirem para desovar no período noturno.

Página I04I Revista Brasileira de Ecoturismo, São Paulo, v.6, n.5, nov 20 I3-jan 20I4, pp. I028-I05I. 


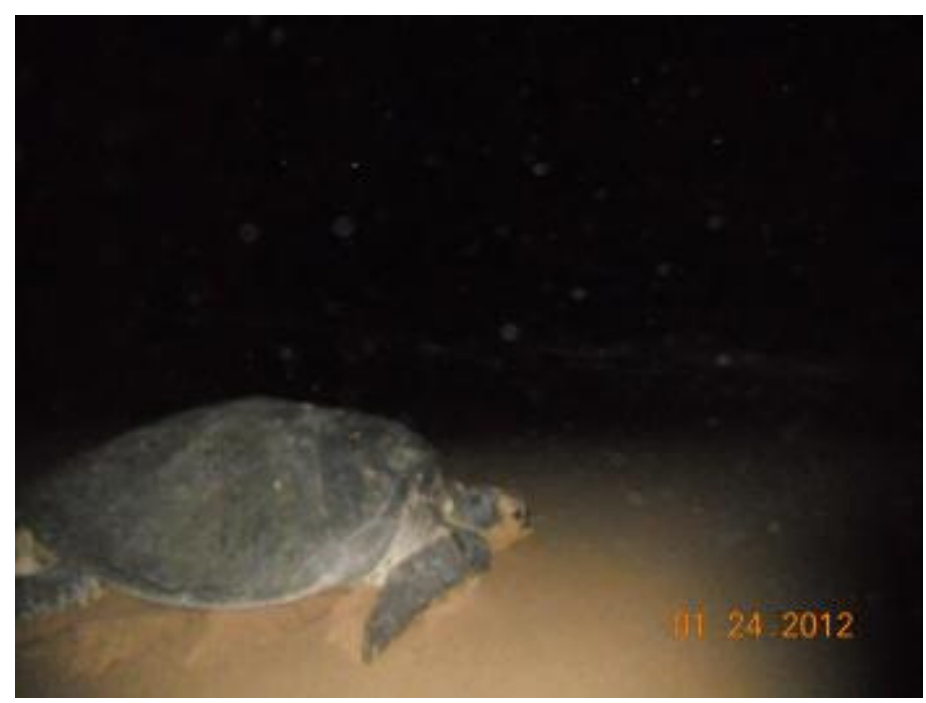

Figura 5: Tartaruga voltando para o mar. Fonte: arquivo pessoal dos autores.

Figure 5: Turtle returning to the sea. Source: author's personal file.

A possibilidade de participar do processo de monitoramento da desova das tartarugas é um diferencial para os turistas que visitam o Arquipélago de Fernando de Noronha. A experiência vivenciada vai além da contemplação de cenários paradisíacos e do registro de paisagens famosas divulgadas em cartões-postais e revistas. Os resultados e as discussões a seguir, pautados nas respostas recebidas no questionário (apêndice 1), apresentam elementos que buscam caracterizar e, em certa medida, "traduzir" a experiência vivenciada pelos turistas durante a "Tartarugada".

\section{Resultados e discussões}

Dentre todos os 105 participantes da atividade, entrevistados em dias aleatórios no período de 23 de janeiro de 2012 a 10 de maio de 2012, 83\% ao menos viram alguma tartaruga-marinha. $\mathrm{O}$ grupo dos participantes que tiveram a oportunidade de flagrar uma tartaruga pode ser dividido entre os que viram atividades reprodutivas e os que não viram.

Neste caso, foi constatado que $81 \%$ dos que viram tartarugas-marinhas também acompanharam a desova. Já a incidência de "meias-luas" (quando a tartaruga sobe, mas não desova) foi testemunhada por $19 \%$ daqueles que chegaram a ver alguma tartaruga. As impressões desse grupo serão analisadas adiante, bem como a opinião das pessoas que sequer viram tartarugas.

A seguir, a análise será iniciada pelas respostas das pessoas que presenciaram a postura de ovos de uma tartaruga-marinha, para em seguida analisar as respostas dos participantes que viram incidências de "meia-lua", finalizando com as impressões daqueles que apenas passaram a noite na Praia do Leão, mas não alcançaram um dos principais objetivos da atividade que seria flagrar uma desova de Chelonia mydas.

Página 1042 Revista Brasileira de Ecoturismo, São Paulo, v.6, n.5, nov 20I3-jan 20I4, Pp.1028-I05I. 


\section{Impressões dos participantes da "Tartarugada" que presenciaram desovas}

Os depoimentos das pessoas que acompanharam todo o processo de desova, desde a procura pelo local ideal até à lenta volta para a água, deixam transparecer o contentamento e a satisfação por terem participado da atividade. Para facilitar a tabulação dos dados, foram apontados no gráfico apenas os termos utilizados mais de uma vez por turistas diferentes. Todas as palavras-chave citadas apenas uma vez estão compreendidas como "Outras", o que correspondeu a 19,6\% das palavras identificadas pelo autor, conforme disposto no Gráfico 1:

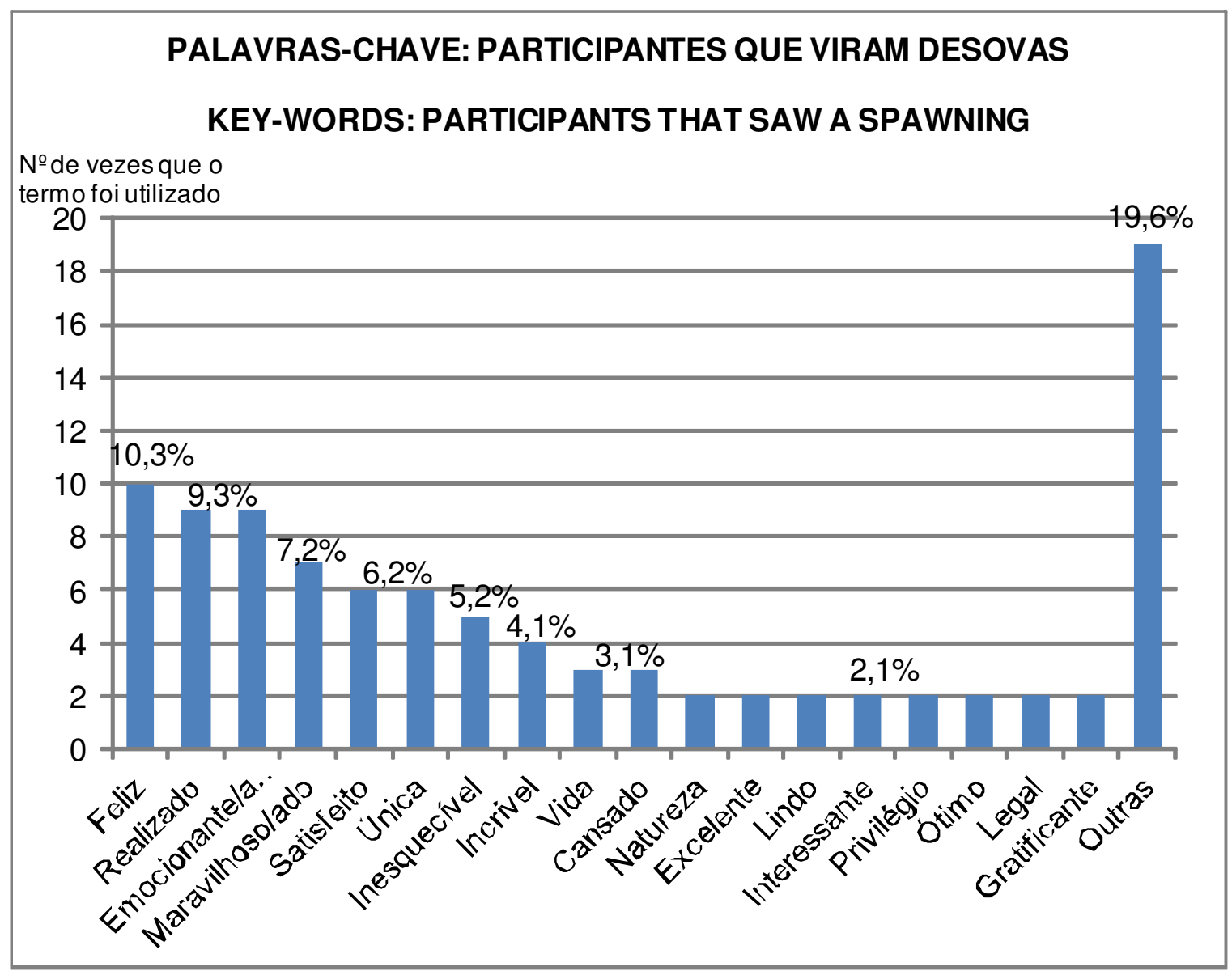

Gráfico 1: percentual de repetição das palavras-chave identificadas nas questões 9 e 11, relativas aos participantes que viram desovas.

Graphic 1: percentage of repetition of key-words identified in the questions 9 and 11, regarding the participants that saw spawnings.

O vocábulo "emoção" e suas variações (emocionante, emocionado) correspondem a 9,3\% dos termos empregados para descrição geral da Tartarugada, juntamente com o termo "realizado(a)". O termo "feliz" foi o de maior incidência nos depoimentos. Também foi reveladora a constatação de que a expressão "experiência única" foi utilizada de forma idêntica por 5 turistas diferentes, em dias

Página 1043 Revista Brasileira de Ecoturismo, São Paulo, v.6, n.5, nov 20 I3-jan 20I4, pp.1028-I05I. 
diferentes. O testemunho de uma desova parece ter suscitado impressões similares em pessoas distintas.

Contudo, o contato com um processo inteiramente natural aparentemente traz emoções diversas à tona. A gama de termos utilizados foi bastante variada, mas é notável a invariável repetição de palavras como "inesquecível", "incrível", "vida" "maravilha", dentre outras acima expostas. A turista C., administradora, 40 anos, de Recife (PE), em resposta à questão "Defina em uma palavra ou frase como se sente após a Tartarugada", escreveu que "não tem como definir" o que sentiu ao presenciar a desova. O médico D., 34 anos, de São Paulo (SP), testemunhou o fato como "a coisa mais linda". O Empresário B., 35 anos, de Bragança Paulista (SP), afirmou: "tive uma das melhores noites da minha vida". A professora A., 34 anos, de Atibaia (SP), entende que foi a experiência mais emocionante de sua vida, como a mesma descreveu; "melhor que o batismo ${ }^{10}$ !". Também é válido observar que, no caso dos que acompanharam a desova, a palavra "cansado" $(3,1 \%)$ geralmente veio acompanhada das conjunções separativas "mas" e "e", seguidas por um termo entendido pelo autor como positivo. As 10 horas de atividade deixam seu saldo de exaustão mesmo com toda a carga emocional vivenciada durante a "Tartarugada".

Também é importante ressaltar que muitos turistas parabenizaram o trabalho dos pesquisadores do TAMAR, que realizam o monitoramento toda noite durante a temporada reprodutiva. Como disse a bióloga E., 42 anos, de Vinhedo (SP), esta é "uma causa que vale a luta", e estes são os seus lutadores, diariamente no fronte da batalha.

\section{Impressões dos participantes da "Tartarugada" que presenciaram "meias-luas"}

Conforme afirma o estudante F., 28 anos, de Barcelona (ESP), nestas ocasiões, "a tartaruga não desovou". O Gráfico 2 apresenta as palavras-chave registradas nos depoimentos dos participantes deste grupo. Nota-se que o fato de não se alcançar o objetivo de ver uma desova parece deixar os participantes mais suscetíveis ao "cansaço", pois variações do termo foram as de maior incidência nos depoimentos (12,5\%), tendo sido citadas 2 vezes. Porém houve um empate com as palavras-chaves "excelente" e "interessante". O comissário de bordo H., 29 anos, de Belo Horizonte (MG), afirma: "adquiri experiência e contato com a natureza". A sensibilização e a satisfação parecem constantes, mesmo entre os que não conseguiram acompanhar aquilo que, em última instância, foi a razão pela qual pagaram a atividade: a desova da tartaruga.

Esse é um resultado bastante interessante do ponto de vista das mudanças de concepções e expectativas da sociedade contemporânea, e o fenômeno turístico pode ser entendido como um termômetro destas alterações. Nos anos 80, Krippendorf ([1989] 2001) se referia aos turistas como bandos desesperados por aproveitar ao máximo aquilo pelo que se dispuseram a pagar; já no século XXI, Irving (2009) enumera razões que apontam algumas mudanças no perfil dos turistas, que estariam mais preocupados com questões relacionadas à agenda ambiental. Esta mudança descrita pela autora vai de encontro aos dados expostos no Gráfico 4. Ou seja, para

Página 1044 Revista Brasileira de Ecoturismo, São Paulo, v.6, n.5, nov 20I3-jan 20I4, Pp.1028-I05I. 
os turistas que presenciaram uma "meia lua", o fato de apenas participar do monitoramento na Praia do Leão e ver uma tartaruga já "vale o preço" que pagaram para a atividade.

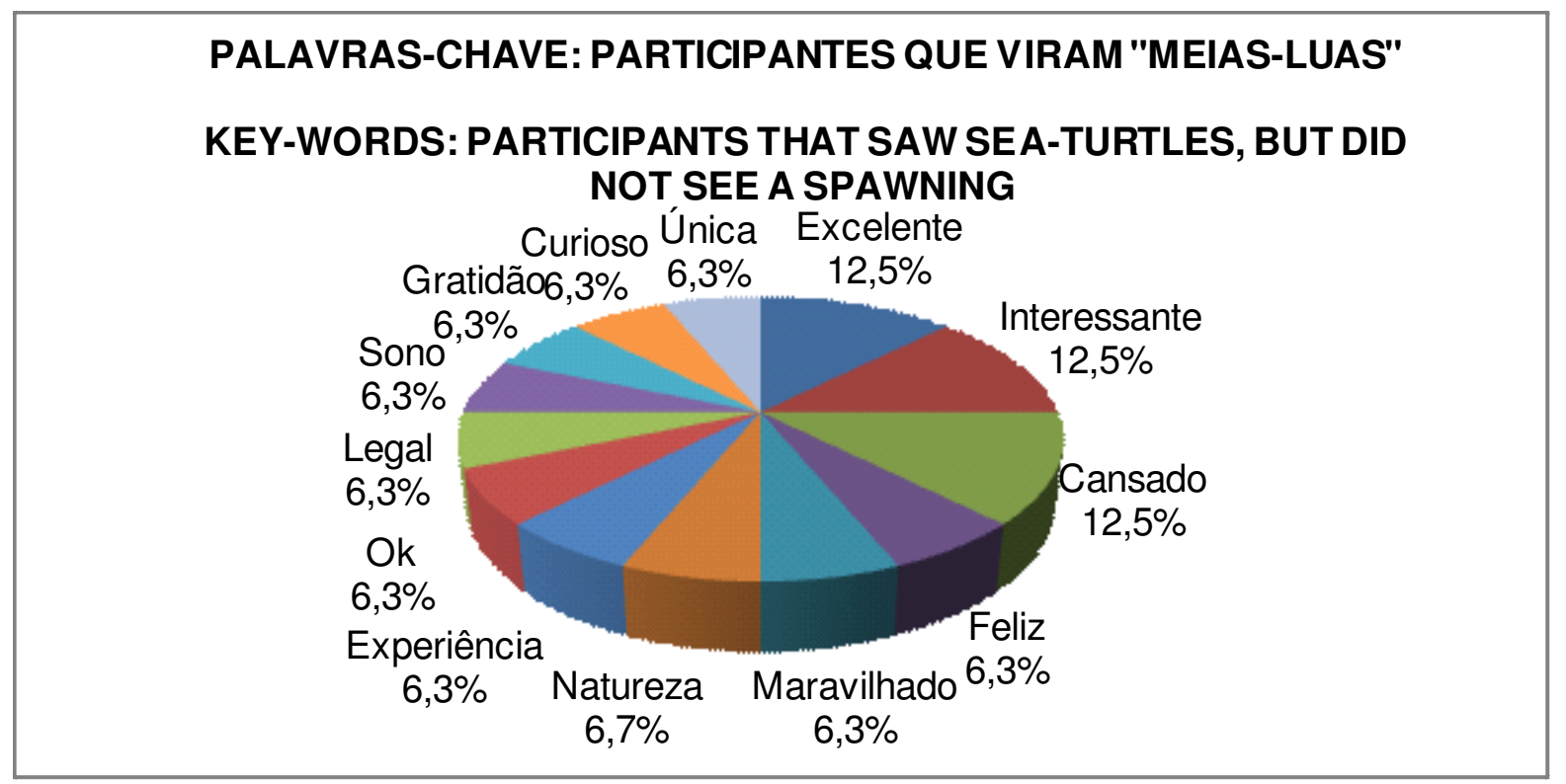

Gráfico 2: percentual de repetição das palavras-chave identificadas nas questões 9 e 11, relativas aos participantes que viram tartarugas, mas não viram desovas.

Graphic 2: percentage of repetition of key-words identified in the questions 9 and 11, regarding the participants that saw sea-turtles, but did not see a spawning.

Também é parte desta análise a observância dos outros termos empregados pelos participantes da atividade. Todas as palavras-chave identificadas estão destacadas no gráfico, mesmo as utilizadas apenas uma vez (6,7\%). Isso foi permitido pelo pequeno espaço amostral (17 pessoas) dos participantes que acompanharam "meias-luas". À exceção do termo "sono", todos os outros 8 termos descritos suscitam alguma conotação positiva. A impressão geral parece ser a traduzido pela turista I., advogada, 29 anos, de Salvador (BA): "experiência maravilhosa, apesar de não ter havido desova".

\section{Impressões dos participantes da "Tartarugada" que não viram tartarugas}

O Gráfico 3 apresenta as palavras-chave informadas pelos turistas que não viram tartarugas. A análise das respostas dos participantes que não viram sequer tartarugas parece otimizar a impressão dos expectadores de meias-luas. Estes participantes não viram nada do que, inicialmente, gostariam de ver. Porém, cabe aqui uma reflexão sobre a sensibilização ambiental, pois mesmo sem presenciar nenhuma tartaruga, o simples fato de acompanhar a atividade de monitoramento e de passar uma noite em "vigília" na praia do Leão, pode despertar emoções e sentimentos que marcam a experiência e o conhecimento adquirido. 
Pinheiro, M.A.P.; Rodrigues, C.G.O.; Robles, R.A.

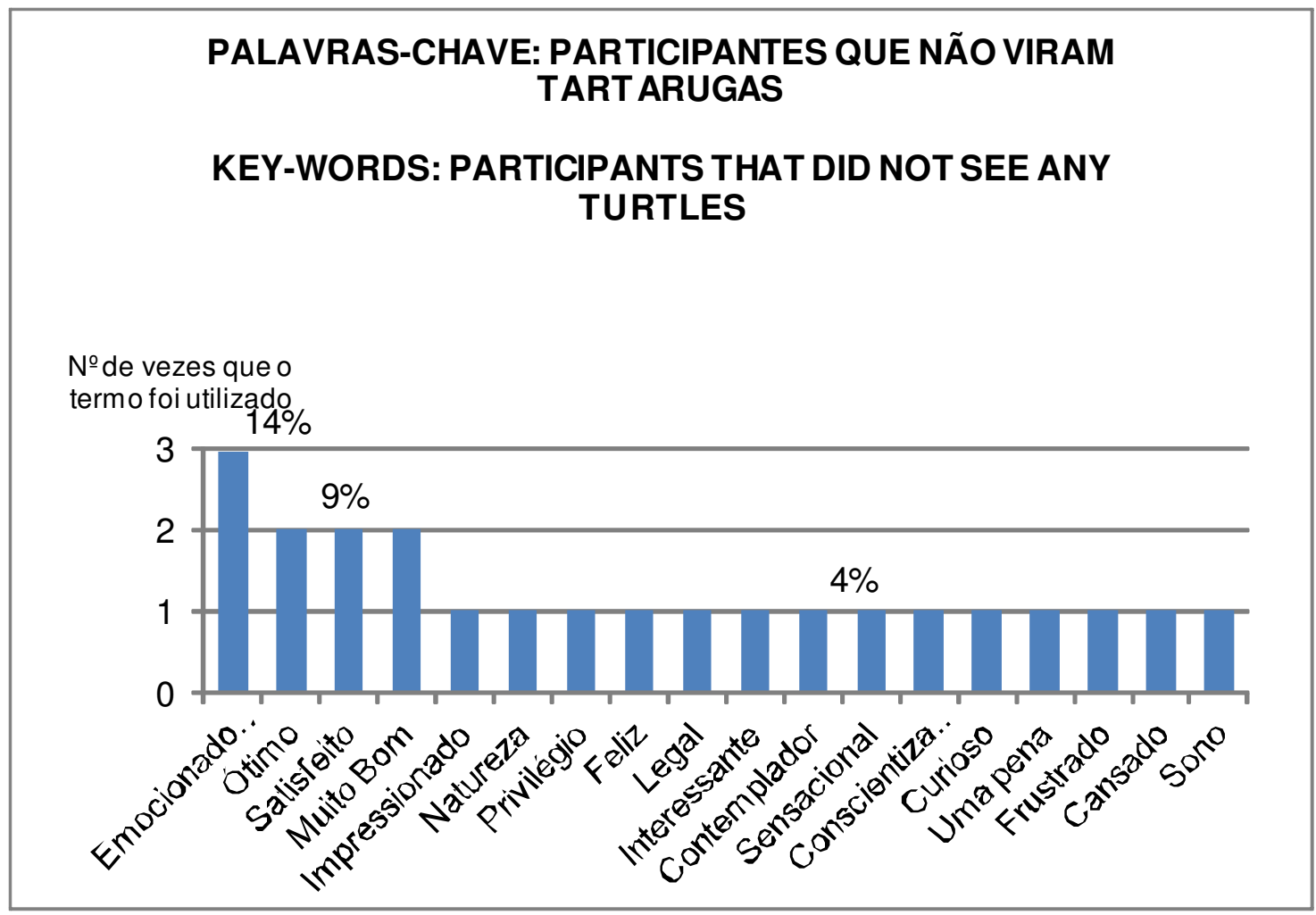

Gráfico 3: percentual de repetição das palavras-chave identificadas nas questões 9 e 11, relativas aos participantes que não viram desovas.

Graphic 3: percentage of repetition of key-words identified in the questions 9 and 11, regarding the participants that did not see spawnings.

Outro prisma de análise interessante da "Tartarugada" é a sua dinâmica de visitação. Essa abordagem é pertinente pelo fato de os pesquisadores do TAMAR não possuírem qualquer tipo de treinamento de monitor de ecoturismo ou algo do gênero. Esse aspecto denota o caráter de "naturalidade" e de "pesquisa" da atividade no que tange à apresentação de informações para os visitantes. Os pesquisadores não possuem um roteiro inteiramente decorado, de datas históricas a nomes científicos de plantas. As informações são fornecidas pelos pesquisadores conforme o interesse dos visitantes e o conhecimento dos biólogos encarregados da atividade. O silêncio noturno, as conversas informais entre rondas, as informações transmitidas com "conhecimento de causa" pelos pesquisadores, o som das ondas e os encontros com ariscos caranguejos transeuntes parecem configurar um bom investimento de tempo e dinheiro para a maioria dos participantes da atividade.

Para a turista G., advogada, 68 anos, do Rio de Janeiro (RJ), que não viu nenhuma tartaruga, a sensação ao fim da noite foi de "paz com a natureza". Segundo Krippendorf ([1989] 2001), as viagens pintam manchas coloridas na tela cinzenta da vida. O cinza desta tela krippendorfiana se deve à poluição e prédios cinzentos dos grandes centros urbanos. O colorido da aquarela noronhense parece ser suficiente

Página 1046 Revista Brasileira de Ecoturismo, São Paulo, v.6, n.5, nov 20I3-jan 20I4, Pp.1028-I05I. 
"Tartarugada": uma iniciativa de sensibilização ambiental no Parna Marinho de Fernando de Noronha

para agradar a maioria dos participantes da atividade. Para reforçar esta linha de raciocínio, basta verificar o vocábulo mais empregado por este grupo: "emoção".

Também é relevante destacar que os termos "frustração", "cansaço", "sono" e "uma pena" foram observados. Mas estes acabaram configurando a exceção amostral, pois os outros 13 termos empregados não suscitam conotações negativas. Todas as palavras-chave identificadas nos questionários dos que não viram tartarugas ou desovas estão apontadas no gráfico acima. Neste caso, o espaço amostral de 18 pessoas, apesar de não ser tão significativo quanto o dos que presenciaram a desova, se mostrou bastante revelador do caráter sensibilizador da "Tartarugada".

As respostas dos questionários indicam que a sensibilização é o elemento principal da atividade, que, assim, tem alcançado seu objetivo primordial. O preço de cinquenta reais por pessoa, que poderia ser considerado um fator negativo, recebeu uma avaliação razoável dos participantes da atividade. $66 \%$ dos turistas entenderam o valor como "bom", $28,3 \%$ indicou a quantia como "razoável" e apenas $5,7 \%$ marcou a opção "ruim". O fato de estar ajudando diretamente o trabalho do Projeto TAMAR com esse investimento provavelmente também influenciou nessa avaliação, o que é mais um indício a favor da sensibilização e engajamento inerentes à atividade.

\section{Considerações finais}

O crescimento das atividades de turismo em contato com a natureza, como o caso do ecoturismo, pode significar uma oportunidade para a sensibilização da sociedade frente à questão ambiental. A "Tartarugada" é uma das iniciativas que seguem essa perspectiva. A sensibilização ambiental parece capilarizar-se em cada uma das 10 horas em que os participantes da atividade se encontram na Praia do Leão, no Parque Nacional Marinho de Fernando de Noronha.

As tartarugas-marinhas têm emocionado e cativado as pessoas que passam por Noronha. A União Internacional para a Conservação da Natureza (IUCN) indica as tartarugas-marinhas como uma das "espécies bandeira ou guarda-chuva". Estes são animais comprovadamente carismáticos, com os quais as pessoas têm uma tendência natural a se afeiçoar (WWF, 2011). Protegendo as tartarugas-marinhas e seu habitat natural, conserva-se todo o ecossistema marinho e costeiro. Daí a alcunha de espécie "guarda-chuva", pois várias espécies estão abrigadas no seu programa de conservação. Portanto, as fascinantes Chelonia mydas noronhenses seguem a manutenção do seu ciclo de vida e levam à mensagem de conservação da natureza para pessoas do mundo todo.

As tartarugas-marinhas, cujas desovas foram assistidas por turistas e moradores em Fernando de Noronha (PE), surgiram na Terra há, pelo menos, 110 milhões de anos; sobreviveram às mudanças climáticas que extinguiram os dinossauros; porém atualmente enfrentam grandes pressões face à captura acidental na pesca, o acúmulo de resíduos nos oceanos, o desenvolvimento desordenado de áreas costeiras e o aquecimento global. Todos estes problemas se configuram na razão determinante para estes animais estarem ameaçados de extinção. Não 
coincidentemente, todos são associados à ação antrópica negativa no ambiente oceânico. A "Tartarugada" é uma atividade que traz à tona essa problemática e busca sensibilizar seus participantes sobre a importância da conservação da biodiversidade, em diversas escalas e frentes de atuação.

\section{Referências bibliográficas}

BELLINI, C.; SANCHES, T.M. First record of a loggerhead turtle in the Fernando de Noronha Archipelago, Brazil. Marine Turtle Newsletter, n. 79, p. 22. Glasgow, 1998.

BELLINI, C.; SANCHES, T.M.; LIMA, R.P. Temporada reprodutiva da tartaruga marinha Chelonia mydas em Fernando de Noronha, PE, Brasil - Campanha: 98/99. Congresso Brasileiro de Zoologia. Anais.... Cuiabá, 2000.

BENSUSAN, N. Conservação da biodiversidade em áreas protegidas. Rio de Janeiro: FGV, 2006.

BRUHNS, H.T. A busca pela natureza: Turismo e Aventura. São Paulo: Manole, 2009.

CAPRA, F. O ponto de mutação: a ciência, a sociedade e a cultura emergente. São Paulo: Cultrix, 2002.

FUNDAÇÃO PRÓ-TAMAR. Assim Nasceu o Projeto TAMAR. Salvador, 2000.

GEERDINK, S.; NEIMAN, Z. A Educação Ambiental pelo Turismo. In: NEIMAN, Z; RABINOVICI, A. (Orgs). Turismo e meio ambiente no Brasil. Barueri: Manole, 2009, p. 63-83.

GOMES, M.G.T.; SANTOS, M.R.D.; HENRY, M. Tartarugas marinhas de ocorrência no Brasil: hábitos e aspectos da biologia da reprodução. Revista Brasileira de Reprodução Animal, v. 30, n. 1/2, p. 19-27. Belo Horizonte, 2006. Disponível em: http://www.cbra.org.br/portal/publicacoes/rbra/2006/rbraji2006.html.

INTERNATIONAL UNION FOR CONSERVATION OF NATURE - IUCN . IUCN Red List of Threatened Species. Version 2012.2. 2012. Disponível em: http:// www.iucnredlist.org. Acesso em: 3 out 2012.

IRVING, M.A. Reinventando a reflexão sobre turismo de base comunitária: inovar é possível?. In: R. BARTHOLO; D.G. SANSOLO; I. BURSZTYN. (Orgs.). Turismo de Base Comunitária. Rio de Janeiro: Letra e Imagem, 2009, p. 108-119.

KRIPPENDORF, J. Sociologia do Turismo: Para uma nova compreensão do lazer e das viagens. São Paulo: Aleph, 2001.

LOHMANN, K.J.; LOHMANN, C.M.F. Detection of magnetic inclination angle by sea turtles: a possible mechanism for determining latitude. Journal of Experimental Biology, v. 194, p. 23-32, 1994.

LUTZ, P.L.; MUSICK, J.A.; WYNEKEN, J. (Ed.). The biology of sea turtles - vol II. Boca Raton: CRC Press, 2003. 
"Tartarugada": uma iniciativa de sensibilização ambiental no Parna Marinho de Fernando de Noronha

MOHR, L.V.; CASTRO, J.W.A.; COSTA, P.M.S.; ALVES, R.J.V. (Orgs.). Ilhas Oceânicas Brasileiras: da Pesquisa ao Manejo - Volume II. Brasília: Ministério do Meio Ambiente/ Secretaria de Biodiversidade e Florestas, 2000.

MORIMOTO, C.; SALVI, R.F. As ércepções do homem sobre a natureza. Encuentro de Geógrafos de América Latina: Caminando en una América Latina en transformación, 12. Anais.... Montevideo, 2009

Projeto TAMAR. SITAMAR - Sistema de Informações do Projeto TAMAR. 2012.

SILVA, M.B.L. Fernando de Noronha: cinco séculos de história - Coleção Cadernos Noronhenses v. 1. Recife: CELPE, 2007.

TEIXEIRA, W.; CORDANI, U.G.; MENOR, E.A.; TEIXEIRA, M.G.; LINSKER, R. Arquipélago Fernando de Noronha: O Paraíso do Vulcão. São Paulo: Terra Virgem, 2003.

VIEITAS, C.F.; MARCOVALDI, M.Â. An ecotourism initiative to increase awareness and protection of marine turtles in Brazil: the Turtle By Night program. Chelonian Conservation and Biology, v.2, n. 4, p.607-610. Massachusetts, 1997.

WORLD WILD FUND FOR NATURE - WWF. Species. 2013. Disponível em: http:// worldwildlife.org/species/marine-turtle. Acesso em: 24 fev 2013.

\section{Notas:}

${ }^{1}$ Sigla oficial em inglês para United Nations Education, Science and Culture Organization.

${ }^{2}$ A IUCN usa critérios próprios para avaliar a biota de acordo com seu potencial risco de extinção. As classificações atuais são: Extinto; Extinto na Natureza; Criticamente em Perigo; Em perigo; Vulnerável; Próximo de Ameaça e Menor Preocupação. Para os animais e plantas de que não se tem informações suficientes, existem as classificações Deficiência de Dados e Não Avaliado (IUCN, 2012).

${ }^{3}$ Sigla oficial em inglês para International Union for Conservartion of Nature.

${ }^{4}$ O Projeto TAMAR está vinculado à Diretoria de Biodiversidade do Instituto Chico Mendes de Conservação da Biodiversidade (ICMBio), autarquia do Ministério do Meio Ambiente (MMA).

${ }^{5}$ Os pesquisadores do TAMAR chamam de meia-lua o processo no qual a tartaruga sobe à areia para desovar, mas por motivos diversos, não o faz, e volta para o mar, deixando um rastro na areia que lembra uma meia-lua.

${ }^{6} \mathrm{O}$ registro "sem desova" é feito quando a tartaruga-marinha sobe à areia, chega a fazer sua "cama" e cavar o ninho, mas não desova.

7 Em Fernando de Noronha, até maio de 2012, 56\% dos empregos gerados pelo TAMAR eram ocupados por ilhéus.

${ }^{8}$ SITAMAR é o banco nacional de dados do Projeto TAMAR que contêm dados específicos sobre os registros e pesquisas sobre as tartarugas-marinhas.

${ }^{9}$ Nomenclatura criada por moradores para designar as praias no lado leste da ilha, virado para a África. As praias a oeste, viradas para o Brasil, compõem o Mar de Dentro.

${ }^{10}$ Entende-se que a turista se referiu ao batismo de mergulho promovido por operadoras de mergulho em Fernando de Noronha. É um mergulho autônomo, com cilindro, em baixas profundidades, feito também com o objetivo de ver como a pessoa se adapta à experiência.

Página 1049 Revista Brasileira de Ecoturismo, São Paulo, v.6, n.5, nov 2013-jan 20I4, pp.1028-I05I. 


\section{Apêndice 1: Questionário Pós-Tartarugada}

1) Dados Pessoais:

Nome: País. Idade: Cidade:

Estado Profissão:

Email:

Biólogo do TAMAR responsável:.

2) Como você ficou sabendo do programa de acompanhamento à Tartarugada?

( ) Palestra no Centro de Visitantes

( ) Na Pousada. Qual?

( ) Cartaz

( ) Guia

( ) Amigo

( ) Revista, Jornal, Televisão.

( ) Outro, Qual?

3) Essa atividade já estava no seu programa de viagem? ( ) Sim （ ) Não

4) Você viu alguma tartaruga? ( ) Sim ( ) Não

5) Foi flagrada alguma tartaruga desovando? ( ) Sim ( ) Não

Em caso afirmativo, responder a questão 6

6) Foi a primeira vez que você viu? ( ) Sim ( ) Não. Se não, onde viu?

7) Assinale a alternativa que melhor expressa sua opinião sobre:

\begin{tabular}{|l|l|l|l|}
\hline & Ruim & Razoável & Bom \\
\hline Esclarecimento prévio sobre a tartarugada & & & \\
\hline Valor cobrado pela atividade & & & \\
\hline Informações durante a tartarugada & & & \\
\hline Relacionamento com o biólogo responsável & & & \\
\hline Atenção do biólogo responsável para com o grupo & & & \\
\hline Instalações do TAMAR & & & \\
\hline Tamanho do grupo & & & \\
\hline Experiência vivenciada & & & \\
\hline
\end{tabular}

8) Você acha que a atividade foi prejudicada devido:
Não poder tirar fotografias
( ) Sim
( ) Não
A falta de luminosidade
( ) Sim
( ) Não
A necessidade de silêncio
( ) Sim
( ) Não
Falta de aviso prévio da atividade
( ) Sim
( ) Não
O tamanho do grupo
( ) Sim
( ) Não
O longo período da Tartarugada
( ) $\operatorname{Sim}$
( ) Não

Página 1050 Revista Brasileira de Ecoturismo, São Paulo, v.6, n.5, nov 20I3-jan 20I4, Pp.1028-I05I. 
"Tartarugada": uma iniciativa de sensibilização ambiental no Parna Marinho de Fernando de Noronha

9) Defina em uma palavra ou frase como se sente após a tartarugada:

10) Você repetiria a atividade? ( ) Sim ( ) Não

11) Deixe seu comentário, crítica ou sugestão sobre a atividade como um todo, utilize o verso da folha.

Miguel Ângelo Portela Pinheiro da Silva: Universidade Federal Rural do Rio de Janeiro, Nova Iguaçu, RJ, Brasil.

Email: miguel.ufrrj@gmail.com

Link para o currículo Lattes: http://lattes.cnpq.br/6149955533674498

Camila Gonçalves de Oliveira Rodrigues: Universidade Federal Rural do Rio de Janeiro, Nova Iguaçu, RJ, Brasil.

Email: camirural@gmail.com

Link para o currículo Lattes: http://lattes.cnpq.br/0553713185190974

Rafael Azevedo Robles: Fundação Pró-Tamar, Fernando de Noronha, PE, Brasil.

Email: rafael@tamar.org.br

Link para o currículo Lattes: http://lattes.cnpq.br/1753647492378860

Data de submissão: 25 de fevereiro de 2013

Data de recebimento de correções: 06 de outubro de 2013

Data do aceite: 06 de outubro de 2013

Avaliado anonimamente

Página I05I Revista Brasileira de Ecoturismo, São Paulo, v.6, n.5, nov 20I3-jan 20I4, pp. I028-I05I. 